American Journal of Agricultural and Biological Sciences 5 (3): 389-396, 2010

ISSN 1557-4989

(C) 2010 Science Publications

\title{
Agriculture Communication in Malaysia: The Current Situation
}

\author{
Md. Salleh Hassan, Hayrol Azril Mohamed Shaffril, Bahaman Abu Samah, \\ Muhamad Sham Shahkat Ali and Nor Sabila Ramli \\ Laboratory of Rural Advancement and Agriculture Extension, \\ Institute for Social Science Studies, University Putra Malaysia, Malaysia
}

\begin{abstract}
Problem statement: Without doubt, it is important to expose and educate farmers with the current and updated agriculture information. To implement this, the related agriculture agencies in Malaysia should consider the best channels for them in spreading the needed valuable agriculture information to the farmers. The question that can be raised now, can the mass media be the right channel for agriculture information dissemination and is the mass media has been utilized in disseminating the agriculture information to the farmers. Approach: This is a conceptual study discussing the usage of mass media in disseminating agriculture information. The data of this study are gained through literature analysis and document analysis. The data is presented descriptively. Results: Based on the analyses done, it was found that majority of Malaysian nowadays can afford to own their own mass media such as television, radio and internet. The number of available television channels, radio channels and newspapers either free or paid are encouraging. Currently, there are three television agriculture programs aired on RTM, while currently there are five agriculture radio programs aired on local radio stations, one program aired on Klasik National FM and the other four programs aired on four different states FM. For newspapers, there are two daily newspapers that provide agriculture information to their readers namely Utusan Malaysia and Berita Harian. Based on the data gained, usage of internet especially on website surfing must be encouraged among the farmers. Mobile web system initiated by five agriculture agencies in Malaysia is seen as a wise step for information dissemination and information sharing. Conclusion: Even though mass media in Malaysia has played its' role in disseminating agriculture information, the number of programs and spaces produced and provided can be doubled, hence it is recommended that local giant agriculture based companies can play their role in providing more fund or sponsorship in producing more agriculture programs for the farmers.
\end{abstract}

Key words: Agriculture communication, farmers development, mass media

\section{INTRODUCTION}

Agriculture has become one of the key factors for development in Malaysia. In the Eight Malaysia Plan and the Ninth Malaysian Plan, the agriculture sector has recorded encouraging growth. Moreover, in the Ninth Malaysian Plan, agriculture is planned to be the third income generator for the country. The government through Ministry of Agriculture and Agro Based Industry (MAAI) and Ministry of Rural and Regional Development (MRRD) has initiated a number of agriculture projects such as TKPM (Sustainable Food Production Park), High Impact Project Zone Industry Aquaculture (HIP ZIA) and Agropolitan project. Recently, the Government has announced that a new Agropolitan project will be initiated at Mukah, Sarawak. Almost USD 8 million will be spend to start the project. All of these mega agriculture projects are proofs of the government efforts to initiate agriculture as the engine of development. Having all these projects is meaningless if the benefited parties which are the farmers and the poor do not take advantage of it. The government's must take efforts to create Knowledgeable and Informed Farmers (KIF). By having KIF, it will aid in making all of the agriculture projects to be successful and this also can be a mechanism for the government to create a sustainable agriculture projects (Bagheri et al., 2008; Gürel, 2005).

To create KIF, it is important to expose farmers with all of the updated agriculture information and by having this it will enhance farmers and the public positive attitude towards agriculture activities (D'Silva et al., 2010). To do this, the related agriculture agencies in Malaysia must choose the right channels to disseminate all the valuable agriculture information to the farmers. The question that can be

Corresponding Author: Md. Salleh Hassan, Laboratory of Rural Advancement and Agriculture Extension, Institute for Social Science Studies, University Putra Malaysia, Malaysia 
raised now, can the mass media be the right channel for agriculture information dissemination. This study would like to focus on four main mass media in Malaysia, namely television, radio, newspaper and the internet. More specifically, this study tries to clarify what currently the four mass media have done in disseminating agriculture information in Malaysia.

Mass media in Malaysia: Before we go to our main objective, it is better for us to get a clearer picture of the four mass media in Malaysia. In this part we will discuss the four mass media components which are television, radio, newspaper and internet. Our discussion will be based on statistics and findings provided by previous studies, AGB Nielsen and Malaysian Communication and Multimedia Commission (MCMC). The current situation in Malaysia has proved that mass media is still the main preference of the farmers. As we can see in Table 1, Md. Salleh et al. (2008) have proved that in terms of mass media preference, television is still the main choice for the farmers in seeking information, entertainment, education and other things. This is followed by newspaper, radio, journal, internet, book, magazine and CD/VCD/Video. This is not surprising as from 2008 till 2010, there are approximately six television channels aired on Radio Television Malaysia (RTM) and Media Prima Berhad and 82 paid satellite channels aired through ASTRO, thus it gives more choices of programs including agriculture programs for the public especially the farmers.

Table 1: Mass media usage among farmers in Malaysia

\begin{tabular}{llll}
\hline & \multicolumn{1}{l}{ Frequency } & & \\
& - & & \\
Sources & Often $(\%)$ & Seldom $(\%)$ & Never $(\%)$ \\
\hline Television & 62.4 & 28.0 & 9.6 \\
Newspaper & 51.8 & 33.8 & 14.4 \\
Radio & 44.4 & 30.7 & 24.9 \\
Journal & 19.0 & 18.2 & 62.8 \\
Internet & 17.8 & 18.7 & 63.5 \\
Book & 17.1 & 36.4 & 46.5 \\
Magazine & 14.0 & 46.2 & 39.8 \\
CD/ Cassette Video & 10.9 & 16.2 & 72.9 \\
\hline
\end{tabular}

Source: Md. Salleh et al. (2008)

Table 2: Percentage of household with television ownership by states

\begin{tabular}{lcc}
\hline States & 2002 & 2004 \\
\hline Johor & 96.1 & 95.4 \\
Kedah & 93.5 & 96.5 \\
Kelantan & 90.9 & 94.0 \\
Malacca & 95.9 & 97.8 \\
Negeri Sembilan & 95.1 & 96.6 \\
Pahang & 94.5 & 95.9 \\
Pulau Pinang & 95.8 & 97.1 \\
Perak & 96.4 & 98.1 \\
Perlis & 95.2 & 95.5 \\
Selangor & 95.0 & 97.8 \\
Terengganu & 92.0 & 92.6 \\
Sabah & 81.3 & 87.1 \\
Sarawak & 89.3 & 97.3 \\
Kuala Lumpur & 97.9 & 93.8 \\
Overall & 93.8 & 95.2 \\
\hline Source: Malaysian & Communication and Multimedia Commission
\end{tabular}

Source: Malaysian Communication and Multimedia Commission (2008)
Television: Currently, there are two government television channels under RTM which are TV1 and TV2, four private television channels under Media Prima Berhad which are TV3, NTV7, TV8 and TV9 and 82 satellite television channels under ASTRO. Based on the recent statistics provided by Malaysian Communication and Multimedia Commission (MCMC), a total of 95.2\% of Malaysian own television (Table 2). This statistics gives us a positive picture that a larger number of people have the possibility to be exposed to agriculture programs aired on television. All of the states in Malaysia, except for Sabah, recorded percentage more than $90 \%$ for television ownership, while Selangor and Malacca (97.8\%) recorded the highest percentage in term of television ownership and Sabah $(87.1 \%)$ recorded the lowest percentage in term of television ownership.

Radio: In term of radio, currently in Malaysia there are 6 national radio stations, 27 state/district radio stations, 21 private radio stations and 9 paid radio stations. Among the popular radio stations are Hot FM, Era FM, Sinar FM, THR Gegar and Klasik Nasional. Referring to the recent statistic provided by MCMC, all of the states in Malaysia recorded a decreasing percentage in term of radio/hi-fi possession. Pahang recorded the highest percentage of decrease with $6.6 \%$ (from $90.6 \%$ in 2002 to $84.0 \%$ in 2004). Even though all the states in Malaysia recorded a decrease in term of radio possession, the current overall percentage of radio possession is $84.5 \%$ which can be considered as high, thus gives a positive possibility that radio also has the same strength as television in disseminating agriculture information (Table 3).

Table 3: Percentage of household with radio/hi-fi possession by states

\begin{tabular}{lcc} 
States & 2002 & 2004 \\
\hline Johor & 89.2 & 87.1 \\
Kedah & 85.3 & 81.5 \\
Kelantan & 81.7 & 85.1 \\
Malacca & 92.8 & 90.8 \\
Negeri Sembilan & 90.9 & 90.3 \\
Pahang & 90.6 & 84.0 \\
Pulau Pinang & 89.3 & 86.2 \\
Perak & 90.4 & 88.2 \\
Perlis & 90.7 & 84.3 \\
Selangor & 90.6 & 88.2 \\
Terengganu & 79.8 & 73.2 \\
Sabah & 76.1 & 73.6 \\
Sarawak & 83.9 & 83.4 \\
Kuala Lumpur & 88.8 & 88.0 \\
Overall & 87.5 & 84.5 \\
\hline Source: Malaysian & Communication and Multimedia Commission \\
(2008) & &
\end{tabular}


Am. J. Agri. \& Biol. Sci., 5 (3): 389-396, 2010

Table 4: Ranking of daily newspaper based on language

\begin{tabular}{ll}
\hline Language & Ranking \\
\hline Malay & Harian Metro \\
& Berita Harian \\
English & Utusan Malaysia \\
& The Star \\
& News Strait Times \\
Chinese & The Sun \\
& Sin Chew Daily \\
Tamil & Guang Ming \\
& Nanyang Siang Pau \\
& Tamil Nesan \\
& Makkal Osai \\
& Malaysian Nanban \\
\hline
\end{tabular}

Source: Nielsen Media Index (2009)

\section{Print media:}

Newspaper: Currently, there are 50 daily newspapers in Malaysia where 13 are in Malay, 16 are in English, 18 are in Chinese and 3 are in Tamil language. This big number means that there are bigger possibilities for more agriculture news to be included in these daily newspapers. Table 4 clarifies to us the top three daily newspapers in each of the main language in Malaysia. Based on Table 4, there is a bigger opportunity for agriculture information to be disseminated to a bigger number of readers if the information is disseminated through Harian Metro, The Star, Sin Chew Daily and Tamil Nesan.

As for magazine, currently there are 82 magazines in Malay language, 194 magazines in English language, 71 magazines in Chinese language and 2 magazines in Tamil language.

Internet: Internet is one of the main tools in seeking information. According to Burke and Sewake (2008) internet has become the major source in seeking information among the farmers. Besides, seeking information, online banking also has already become an important element of agri-business activity of farmers. In Malaysia, based on the recent statistic provided by MCMC, majority of Malaysian used internet for the purpose of seeking information $(94.4 \%)$, followed by communicating through text $(84.7 \%)$ and education $(64.5 \%)$. Interestingly, all of the purposes of internet usage listed by MCMC recorded increase in percentage from 2006-2008. Based on the top three purposes of internet usage, related agriculture agencies such as Ministry of Agriculture and Agro-Based Industry (MAAI), Department of Agriculture (DOA) and Department of Fisheries (DOF), must think wisely the effective strategies in utilizing their websites for providing agriculture information which directly can educate the farmers. Besides, the related agencies must think about how to connect all the farmers through online communication services (ex: Chat) that can be provided in their official websites. This can extend and widen the linkage and networking for the farmers (Table 5).
Table 5: Internet usage purposes

\begin{tabular}{lll}
\hline Internet usage purposes & $\begin{array}{l}\text { Percentage of } \\
\text { usage in 20006 }\end{array}$ & $\begin{array}{l}\text { Percentage of } \\
\text { usage in 2008 }\end{array}$ \\
\hline Seeking information & 84.5 & 94.4 \\
Communicating through text & 80.7 & 84.7 \\
Education & 52.6 & 64.5 \\
Leisure time & 45.9 & 63.5 \\
Financial activities & 23.6 & 31.8 \\
Public services & 12.0 & 29.2 \\
e-government transaction & - & 19.8 \\
Online stock transaction & - & 5.9 \\
Others & 0.2 & 0.7 \\
\hline Source: Malaysian Communication and Multimedia Commission &
\end{tabular}

Table 6: Ranking of search engines in Malaysia

\begin{tabular}{ll}
\hline Number & Search engine \\
\hline 1 & Yahoo.com \\
2 & youtube.com \\
3 & live.com \\
4 & google.com \\
5 & myspace.com \\
6 & facebook.com \\
7 & msn.com \\
8 & hi5.com \\
9 & wikipedia.org \\
10 & orkut.com \\
\hline
\end{tabular}

Source: Murphy (2008)

Table 6 indicates the 10 most search engines used by Malaysian public in seeking and sharing information. The statistic obviously indicates that search engines such as yahoo.com, you.tube.com, live.com, google.com and myspace.com are among the top choices of Malaysians (Murphy, 2008).

\section{MATERIALS AND METHODS}

This is a conceptual study where the data is gained through literature analysis and document analysis. The data of this study are presented descriptively.

Agriculture communication in Malaysia: The success of agricultural development program in developing countries largely depends on the nature and extent of use of mass media in mobilization of people for development. The planners in developing countries should realize that the development of agriculture can be further strengthened through the effective utilization of mass media. Mass media such as television, radio, newspaper and of course the internet have been proven to be the most effective media for diffusing the agriculture knowledge to the masses.

In Malaysia, based on the statistics and facts given, it can be proved that mass media has a huge potential to be developed as the major channel for dissemination of agriculture information. Most of the Malaysians are able to posses mass media, thus creating a probability 
that there is a higher percentage of the message of the mass media that can be received by the Malaysians. The next topic will bring us to the current agriculture communication in Malaysia. We will discuss more deeply regarding the usage of four main mass media namely television, radio, newspaper and internet in disseminating agriculture information to the Malaysian public.

Television: All of the current television agriculture programs are aired by RTM through its two television channels, TV1 and TV2. The agriculture programs are produced under the Unit of Documentary and Magazine previously known as Unit of Agriculture and Development. Before, private television channel, NTV 7 owned by giant media company, Media Prima, had produced an agriculture program known as Seed. Another channel of Media Prima, TV3, through its famous documentary program "Majalah Tiga" has a number of times produced issues on new agriculture products and technologies. Currently, there are three agriculture programs produced by RTM aired on TV1 and TV2 and the description of the programs are as below. One agriculture program known as Agro Asian was stopped at the end of 2009 due to financial problem.

Agro Tech: Agro Tech is one of the top rated programs in the Unit of Documentary and Magazines. Agro Tech is an agriculture program in a magazine form. Currently, it has three segments namely profile, R\&D and technology. The program is hosted by a host or interviewer at a selected location. There are no rigid format for each episode. It depends on suitability, current situation and the program demands. This program is hoped to aid farmers, livestock breeders and fishermen to increase their productivity, competitiveness and skills as well as be informed regarding the new technology

Agro Journal: Agro Journal is a documentary program focusing on agriculture activities in Malaysia. Besides, it also emphasizes on current issues concerning farmers, fishermen, small medium entrepreneurs and commodity industry. Each of the produced issue will be presented educationally and analytically. One of the objectives of this program is to fulfill the social obligation in attracting the public to be part of the agriculture industry in Malaysia. Agro Journal is hoped to raise consciousness among the audience in Malaysia especially on issues related to agriculture. This is in line with MAAI slogan "agriculture is a business".

Our Earth: Our Earth is a program which act as a filler in RTM. Our Earth has no specific air time or day. The main purpose of this program is to fill the time gap that exists between two programs aired in RTM. The content program of our earth is a summarization made from either Agro Journal or Agro Tech.

Agro Asian: Agro Asian is a continuity of the previous agriculture program aired on RTM known as Agro ASEAN. However, Agro Asian has been stopped in 2009 due to financial problems. Agro Asian conducted its shooting in Korea, Taiwan and China due to higher and advanced agriculture technology these countries have. It is a hope that farmers in Malaysia can take examples from these countries and apply it on their agriculture activities. Agro Asian viewers are exposed to new technology, study culture, spirit and hard study among the farmers from these three countries. Agro Asian is hoped to assist the government in elevating agriculture sector in line with the goals and aspirations of the government in developing agriculture and making it as the major contributor to the income of the nation (Table 7).

Print media: Print media is the earliest form of mass media used in Malaysia. The first newspaper was published in Malaysia in the year 1805. Printed media, especially newspaper has a huge potential in disseminating agriculture information. Among the several print media, newspaper and magazine are most commonly used. These two print media have an essential role to play in the communicating the agricultural information to the farmers. Problem of literacy is not anymore a major problems in Malaysia, thus it offers new promises and prospects for utilizing print medium as a means of agriculture information dissemination. The print media provide a wider scope of communication. Compared to other type of mass media, print media is cheaper, thus a lot of people can afford to buy it. It is a permanent medium in that the message are imprinted permanently with high storage value which makes them suitable for reference and research. Print media has a huge potential in dissemination of information on improved agricultural practices to the farmers and also to inform the public in general. In this part, we will specifically discuss agriculture communication though print media in Malaysia.

Newspaper: There are only two daily newspapers that have agriculture segment in their spaces. Utusan Malaysia has newspaper insert called Agrobiz. Agrobiz is published every Monday. The contents of Agrobiz focus on the new technology and the story of successful ago-based entrepreneurs. From Agrobiz it is hoped that farmers in Malaysia will be informed and highly motivated when they read about the success of their colleagues. Berita Harian is another daily newspaper that has the agriculture segment. The agriculture segment is sponsored by Malaysian Palm Oil Board (MPOB) and is published once a month. 
Am. J. Agri. \& Biol. Sci., 5 (3): 389-396, 2010

Table 7: Agriculture television program information

\begin{tabular}{|c|c|c|c|c|}
\hline Agriculture programs & Day & Time & Duration & Channels \\
\hline Agro Tech & Saturday & $6.31 \mathrm{pm}$ & $30 \mathrm{~min}$ & TV1 \\
\hline Agro Journal & Sunday & $6.30 \mathrm{pm}$ & $30 \mathrm{~min}$ & TV1 \\
\hline Our Earth & $\begin{array}{l}\text { No specific day, act as filler } \\
\text { to fill the time gap exist } \\
\text { between two television } \\
\text { programs }\end{array}$ & $\begin{array}{l}\text { No specific time, act as filler } \\
\text { to fill the time gap exist } \\
\text { between two television } \\
\text { programs }\end{array}$ & Based on the requirements & TV1 and TV2 \\
\hline
\end{tabular}

Table 8: Agriculture radio program information

\begin{tabular}{llll}
\hline Radio channel & Agriculture program & Day & Time \\
\hline Klasik National FM & Agriculture Best *Best Tani & Wednesday and Thursday & $12.30-1.00 \mathrm{pm}$ \\
Selangor FM & Agriculture in new Millennium & Tuesday and Thursday & $11.30-12.00 \mathrm{pm}$ \\
& *Pertanian Alaf Baru & Monday & $11.15 \mathrm{am}-12.00 \mathrm{pm}$ \\
Pahang FM & Prosperous Earth *Bumi Makmur & Tuesday & $12.00-12.30 \mathrm{pm}$ \\
Kedah FM & Perspiration Services *Keringat Bakti & Thursday & $12.00-1.00 \mathrm{pm}$ \\
Perlis FM & Success Track *Jejak Jaya &
\end{tabular}

*: Program name in Malay

Magazine: Magazines in Malaysia can be considered as a popular type of print media after newspaper. Currently there are a total of 349 types of magazines published in four main languages in Malaysia which are Malay, Chinese, English and Tamil. Agriculture News is one of the main agriculture magazines in Malaysia. Besides, Agrobiz, a newspaper insert by Utusan Malaysia is produced in a magazine format through cooperation between Utusan Malaysia and DOA. Other magazines such as Garden Asian, Going Places and Community Hall have provided spaces in their magazine for DOA.

Radio: Previous study by Okwu et al. (2007) indicated that radio can be an agent of change to the agriculture community. Okwu et al. (2007) found that majority of the farmers indicated that the agriculture radio programs aired were relevant to their agricultural information needs. Through radio agriculture program, some new knowledge can be gained through listening to the programs. Earlier, in Malaysia, radio was used as a main tool in bringing changes to the farmers. The benefits of agriculture activities were informed to the public through popular radio agriculture programs by that time known as "Siaran Kemajuan Kampung" and "Halaman Pertanian". Currently, there are one national radio FM which is Klasik National FM that air agriculture program known as Agriculture Best. The program is aired for 30 min from $12.30-1.00 \mathrm{pm}$ Besides national radio station, there are four states radio stations that have their own agriculture programs. States FM such as Selangor FM, Pahang FM, Kedah FM and Perlis FM must be praised for putting their effort in producing agriculture programs. Table 8 illustrates to us information regarding the current agriculture programs aired on national and states radio channels.
Table 9: Internet applications used by farmers

\begin{tabular}{|c|c|c|c|}
\hline Variables & Frequency & Percentage & Mean \\
\hline E-mail & & & 1.14 \\
\hline None $(0)$ & 30 & 18.3 & \\
\hline Seldom $(0.01-1)$ & 81 & 49.4 & \\
\hline Always (1.01-2) & 53 & 32.3 & \\
\hline Website surfing & & & 1.12 \\
\hline None $(0)$ & 43 & 26.2 & \\
\hline Seldom (0.01-1) & 58 & 35.4 & \\
\hline Always (1.01-2) & 63 & 38.4 & \\
\hline $\mathrm{B} \log$ & & & .57 \\
\hline None $(0)$ & 95 & 57.9 & \\
\hline Seldom (0.01-1) & 45 & 27.4 & \\
\hline Always (1.01-2) & 24 & 14.7 & \\
\hline Bulletin board & & & .51 \\
\hline None $(0)$ & 100 & 61.0 & \\
\hline Seldom (0.01-1) & 45 & 27.4 & \\
\hline Always (1.01-2) & 19 & 11.6 & \\
\hline Yahoo Messenger & & & .48 \\
\hline None $(0)$ & 104 & 63.4 & \\
\hline Seldom (0.01-1) & 42 & 25.6 & \\
\hline Always (1.01-2) & 18 & 11.0 & \\
\hline Chat & & & .43 \\
\hline None $(0)$ & 105 & 64.0 & \\
\hline Seldom (0.01-1) & 48 & 29.3 & \\
\hline Always (1.01-2) & 11 & 6.7 & \\
\hline Mailing list & & & .37 \\
\hline None $(0)$ & 112 & 68.3 & \\
\hline Seldom (0.01-1) & 44 & 26.8 & \\
\hline Always (1.01-2) & 8 & 4.9 & \\
\hline Agriculture forum online & & & .35 \\
\hline None $(0)$ & 117 & 71.3 & \\
\hline Seldom (0.01-1) & 36 & 22.0 & \\
\hline Always (1.01-2) & 11 & 6.7 & \\
\hline
\end{tabular}

Source: Md. Salleh and Hayrol Azril (2009)

Internet: Internet offers a lot of applications that has a lot to offer to the farmers. According to Sanchez (2000) and Little (2000), farmers nowadays prefer to utilize internet applications such as websites, blog, e-mail and online forum to buy goods and services, cut deals, attend auctions, expand markets and reduce costs. In Malaysia, based on the recent study done by Md. Salleh and Hayrol Azril (2009) (Table 9) proved that among the internet applications, farmers frequently use e-mail. 
There is s possibility that related agriculture agencies can initiate a system that can disseminate automatically the updated agriculture information to all of the farmers in Malaysia through e-mail. Besides e-mail, farmers were also found to frequently surf websites. However effective strategies must be taken into account on how to educate farmers in using mailing list and agriculture forum online since these two internet applications are less popular among farmers in Malaysia.

Based on the previous study done by Burke and Sewake (2008), farmers who have their own website agreed that the website will bring profit to their agrobusiness. Muske et al. (2004) have other view where they found that possessing and surfing website will increase their agro-business productivity. According to Barton (2003), the website provides farmers with the ability to communicate over long distances with other farmers, agribusiness and universities. In fact, website is considered to be one of the most popular online services for farmers, considering that it is often cheaper than the telephone. While in Malaysia, based on the recent study done by Hayrol Azril et al. (2009b), who have specifically studied on the agriculture based websites surfed by the farmers in Malaysia concluded that farmers must be strongly encouraged to surf agriculture websites in seeking and sharing valuable agriculture information. The effective strategies in encouraging agriculture website surfing must be instantly be planned by the related agencies based on the lowest mean score recorded by all of the websites listed. Based on Table 10, it can be seen that the official website of Department of Agriculture (www.doa.gov.my) is the most surfed website among the farmers, followed by the official website of Malaysian Research and Development Institute (www.mardi.gov.my) and the official website of Federal Agriculture Marketing Authority (FAMA) (www.agrolink.moa.my.fama).

Mobile web: Mobile phone has been admitted by farmers in assisting them in getting valuable agriculture information (Hayrol Azril et al. 2009a). Accurate and timely information is indeed important to decide on right decisions. It is widely acceptable that information plays a significant role in agriculture sector where success is based on having access to the right person with the right information and at the right time. Admitting the importance of mobile phone, some developing countries have developed a mobile web system specifically for the farmers in their country. Mobile web system is a new trend of offering services and providing updated information and technologies by government agriculture agencies to the farmers. In countries such as India, China and Kenya, mobile web system has been used widely for the purpose of marketing and irrigation control (Ribeiro, 2009).

Table 10: Internet applications used by farmers

\begin{tabular}{|c|c|c|c|c|}
\hline \multirow[b]{2}{*}{ Name of agro-based website } & \multicolumn{4}{|c|}{ Percentage } \\
\hline & 0 & 1 & 2 & Mean \\
\hline Department of Agriculture Malaysia www.agrolink.moa.my/doa & 70.0 & 22.9 & 7.1 & 0.37 \\
\hline $\begin{array}{l}\text { Malaysian Agriculture Research and Development Institute } \\
\text { www.mardi.my }\end{array}$ & 76.9 & 18.4 & 4.7 & 0.28 \\
\hline Federal Agriculture Marketing Authority (FAMA) & 79.3 & 15.6 & 5.1 & 0.26 \\
\hline www.agrolink.moa.my/fama Farmers Organization Authority (FOA) & 84.2 & 10.7 & 5.1 & 0.21 \\
\hline $\begin{array}{l}\text { www.agrolink.moa/lpp Agriculture Bank of Malaysia } \\
\text { www.agrobank.com.my }\end{array}$ & 84.2 & 13.6 & 2.2 & 0.18 \\
\hline Department of Fisheries Malaysia www.agrolink.moa.my.dof & 85.6 & 11.6 & 2.9 & 0.17 \\
\hline Malaysia Palm Oil Board (MPOB) www.mpob.gov.my & 89.3 & 8.7 & 2 & 0.13 \\
\hline $\begin{array}{l}\text { University Putra Malaysia (Agriculture Based University) } \\
\text { www.upm.edu.my }\end{array}$ & 89.1 & 9.3 & 1.6 & 0.12 \\
\hline Department of Veterinary Services www.agrolink.moa.my.jph & 90.2 & 7.1 & 2.7 & 0.12 \\
\hline $\begin{array}{l}\text { Federal Land Consolidation and Rehabilitation Authority (FELCRA) } \\
\text { www.felcra.com.my }\end{array}$ & 88.9 & 10.2 & 0.9 & 0.12 \\
\hline $\begin{array}{l}\text { Rubber Industry Smallholder Development Authority (RISDA) } \\
\text { www.risda.gov.my }\end{array}$ & 91.1 & 7.8 & 1.1 & 0.1 \\
\hline
\end{tabular}

Source: Hayrol Azril et al. (2009b)

Table 11: Mobile web services offered by agriculture agencies in Malaysia

\begin{tabular}{ll}
\hline Agriculture agencies & Address \\
\hline Ministry of Agriculture and Agro-based Industry & www.moa.gov.my/mobile \\
Department of Agriculture & www2.doa.gov.my/mobile/main.htm \\
Rubber Industry Smallholders Development Authority & www.risda.gov.my $/ \mathrm{mobile}$ \\
Malaysian Pineaple Industry Board & www.mpib.gov.my $/ \mathrm{mobile} /$ \\
Kemubu Agriculture Development Board & www.kada.gov.my/web/guest $/ \mathrm{mobile}$ \\
\hline
\end{tabular}

Note: $0=$ Never, $1=$ Seldom, $2=$ Always 
Malaysia has also followed what these countries have done. A number of agriculture agencies in Malaysia have created their own mobile web system (Table 11).

Department of Agriculture roles in disseminating agriculture information using mass media: Department of Agriculture Malaysia (DOA) as one of the main agriculture agencies in Malaysia has fully utilize the advantage mass media has in disseminating valuable agriculture information to the farmers. For printed media, DOA has published 17 types of printed publications in a form of book, handbook, brochure, leaflet, calendar, magazine and annual report. DOA is one of the main sources for newspaper insert called Agrobiz.

DOA also cooperates with RTM in producing agriculture programs either in television or in radio. Once a year DOA will be invited to a meeting held by RTM in determining the suitable agriculture program to be produced on that year. What to be produced, where to go and who to be interviewed is determined and suggested by DOA and RTM will prepare the script. DOA also has a couple of times advertised their products on private television channel, TV8 and TV9.

Internet has played a significant role in assisting DOA in providing and disseminating agriculture information and related services to the public especially the farmers. Through their official website www.doa.gov.my, all of the updated information such as news, new technologies and new products are available. Some of their printed materials also are available online. Furthermore, DOA has started to introduce the mobile web services which have proved to be a successful method in disseminating agriculture information in country such as China and India.

\section{RESULTS AND DISCUSSION}

For television, effort by RTM can be followed by other media organizations such as Media Prima and ASTRO. As we know these two giant media companies have a huge number of viewers and have a bigger potential and ability in producing attractive agriculture programs. The popularity of these two companies can be used in attracting the public to watch television agriculture programs. Local giant agriculture based companies such as BioTech Corp and Sime Darby can play their role in providing bigger fund in producing agriculture programs.

There is little discussion of diversification in print media. Currently, there are only two daily newspapers that have their own agriculture segments, while for magazines, the number of agriculture magazine is not encouraging. Without more attention to diversification of print media, the public and policy makers will be illinformed about opportunities and obstacles in this regard.

For radio, the number of radio channels that have agriculture programs is not encouraging. There are only four states FM that have agriculture programs. Supposedly, the other nine states FM in Malaysia should initiate efforts to produce their own agriculture programs. They must do this as states FM are more closer to the listeners. Besides, high rated radio channels such as Hot FM and Era FM can play a vital role in disseminating agriculture information. In this case, again, giant agriculture companies can provide a bigger fund or sponsorship to these radio channels in producing agriculture based program.

Strategies in encouraging farmers to use internet must be reorganized, government strategies in initiating agenda such as National Information Technology Agenda (NITA) and Universal Services Provider (USP) must be strengthened. Based on the findings from the previous studies, farmers seem not to have benefited from the impact that these two agendas brought.

\section{CONCLUSION}

Even though mass media in Malaysia has played its' role in disseminating agriculture information, the number of programs and spaces produced and provided can be doubled, hence it is recommended that local giant agriculture based companies can play their role in providing more fund or sponsorship in producing more agriculture programs for the farmers.

\section{REFERENCES}

Bagheri, A., H.S. Fami, A. Rezvanfar, A. Asadi and S. Yazdani, 2008. Perceptions of paddy farmers towards sustainable agricultural technologies: Case of Haraz catchments area in Mazandaran province of Iran. Am. J. Applied Sci., 5: 1384-1391. http://www.scipub.org/fulltext/ajas/ajas5101384-1391.pdf

Barton, H., 2003. New Zealand farmers and the internet. Br. Food J., 105: 96-110. DOI: 10.1108/00070700310467519

Burke, K. and K. Sewake, 2008. Adoption of computers and internet technology in small firm agriculture: A study of flower growers in Hawaii. J. Exten., 46: 5-19.

D'Silva, J.L., H.A.M. Shaffril, J. Uli and B.A. Samah, 2010. Socio-demography Factors that Influence Youth Attitude towards contract farming: A case from Peninsular Malaysia. Am. J. Applied Sci., 7: 603-608.

http://www.scipub.org/fulltext/ajas/ajas74603-608.pdf 
Gürel, A., 2005. Organizations and activities of a new leading farmer extension model in Turkey. Am. J. Environ. $\quad$ Sci., $\quad$ 1: 5-10. http://www.scipub.org/fulltext/ajes/ajes115-10.pdf

Hayrol Azril, M.S., H. Md. Salleh, A.H, Musa and L.S. Jeffrey, 2009a. Agro-based industry, mobile phone and youth: A recipe for success. Eur. J. Sci. Res., 36:

41-48. http://www.eurojournals.com/ejsr_36_1_05.pdf

Hayrol Azril, M.S., H, Md. Salleh and A.S. Bahaman, 2009b. Level of agro-based websites surfing among Malaysian agricultural entrepreneurs: A case of Malaysia. J. Agric. Soc. Sci., 5: 55-60. http://www.fspublishers.org/jass/pastissues/JASSVOL_5_NO_3/1.pdf

Little, D., 2000. Old MacDonald has a web site online exchanges for farmers are cutting costs for seed, feed and chemicals while boosting prices for products. BUSINESSWEEK ONLINE. http://www.businessweek.com/2000/00_20/b36810 99.htm

Md. Salleh, H. and M.S. Hayrol Azril, 2009. Internet usage among agro-based entrepreneurs: Can it affects productivity. J. Agric. Soc. Sci., 5: 61-66. http://www.fspublishers.org/jass/pastissues/JASSVOL_5_NO_3/2.pdf

Md. Salleh, H., A.H. Musa, A.S. Bahaman and M.S. Hayrol Azril, 2008. Agricultural based entrepreneurs usage of ICT-problems and prospect. Proceeding of the World Conference on Agricultural Information and ICT, Aug. 24-27, AALD, Tokyo, Japan, pp: 753-762.
Murphy, S., 2008. Insights into critical trends that are shaping the lives of Malaysian consumers. Synovate Ltd. http://www.adoimagazine.com/newhome/images/ docs $/ 5 \% 20$ hot $\% 20$ trends\%20for\%20Malaysia.pdf

Muske, G., N. Stanford and M.D. Woods, 2004. Micro business use of technology and extension's role. J. Exten., 42: 1-8.

Okwu, O.J., A.A. Kuku and J.I. Aba, 2007. An assessment of use of radio in agricultural information dissemination: A case study of radio Bunue in Nigeria. Afr. J. Agric. Res., 2: 14-18. http://www.academicjournals.org/AJAR/PDF/Pdf2 007/Jan/Okwu\%20et\%20al.pdf

Ribeiro, J., 2009. Indian farmers use mobile phone to control irrigation. PCWorld Business Center. http://www.pcworld.com/businesscenter/article/16 8895/indian_farmers_use_mobile_phones_to_contr ol_irrigation.html

Sanchez, S., 2000. E-commerce profile: Farmbid.com: Creating a one-stop shop. Agric. Market., 38: $5-5$. 